\title{
DETERMINANT OF COVID-19 PREVENTION BEHAVIOR IN THE COMMUNITY IN PAMULANG, SOUTH TANGERANG IN 2021
}

\author{
${ }^{1}$ Munaya Fauziah, ${ }^{2}$ Oswin Yohsa Ibrahim, ${ }^{3}$ Nur Romdhona, ${ }^{4}$ Ernyasih \\ ${ }^{1-4}$ Faculty of Public Health, Muhammadiyah University of Jakarta \\ KH. Ahmad Dahlan Street, Cireundeu, Ciputat, South Jakarta, 15419 \\ Email: munaya.fauziah@umj.ac.id
}

\begin{abstract}
ABSTRAK
Coronavirus Disease 2019 (COVID-19) merupakan penyakit menular yang disebabkan oleh SARSCoV-2. Perilaku pencegahan pada masyarakat penting dilakukan guna menjaga kesehatan di masa pandemi. Penelitian ini bertujuan untuk mengetahui determinan perilaku pencegahan COVID-19 pada Masyarakat di Kelurahan Bambu Apus, Kecamatan Pamulang tahun 2021. Penelitian analitik kuantitatif dengan pendekatan cross sectional dilakukan di RW. 001 Kelurahan Bambu Apus pada bulan Juni-Juli 2021 dengan responden 180 responden dan menggunakan metode sampel Probability Proportional to Size Sampling (PPS). Berdasarkan hasil analisis univariat didapatkan bahwa responden berumur $\geq 40$ tahun $(55,6 \%)$, berjenis kelamin perempuan $(59,4 \%)$, memiliki pendidikan tinggi $(92,8 \%)$, bekerja $(62,2 \%)$, pengetahuan yang baik $(80 \%)$, sikap positif $(78,3 \%)$, sumber informasi bersumber pada jejaring sosial $(60 \%)$, dukungan keluarga yang baik $(55 \%)$, dukungan petugas kesehatan yang baik $(61,1 \%)$ dan perilaku pencegahan COVID-19 yang baik $(85 \%)$. Berdasarkan hasil analisis bivariat didapatkan terdapat hubungan yang bermakna antara pengetahuan $(p$-value $=0,000)$, sikap $(p$-value $=$ $0,000)$, dukungan keluarga ( $p$-value $=0,000)$, dukungan petugas kesehatan $(p$-value $=0,000)$ dengan perilaku pencegahan COVID-19 pada masyarakat di Wilayah RW. 001 Kelurahan Bambu Apus, Kecamatan Pamulang. Namun tidak ditemukan hubungan antara umur $(p$-value $=0,529)$, jenis kelamin $(p$-value $=0,848)$, pendidikan $(p$-value $=0,417)$, pekerjaan $(p$-value $=0,155)$, sumber informasi $(p$ value $=1,000)$, dengan perilaku pencegahan COVID-19. Sedangkan sumber informasi tidak memiliki hubungan yang bermakna $(\mathrm{p}=1,000)$. Saran terkait hasil penelitian diharapkan pengurus RW dapat bekerjasama dengan petugas kesehatan untuk meningkatkan pengetahuan, sikap serta dukungan keluarga terkait perilaku pencegahan COVID-19 dengan mendorong, mengingatkan serta mengedukasi masyarakat terkait COVID-19.
\end{abstract}

Kata Kunci: Masyarakat, Perilaku Pencegahan, Covid-19

\section{ABSTRACT}

Coronavirus Disease 2019 (COVID-19) is an infectious disease caused by SARS-CoV-2. Preventive behavior in the community is important to maintain health during a pandemic. This study aims to determine the determinants of COVID-19 prevention behavior in the community in Bambu Apus, Pamulang in 2021. The approach was conducted in RW. 001 Bambu Apus in June-July 2021 with 180 respondents and using the Probability Proportional to Size Sampling (PPS) sample method. Characteristics of respondents found that the majority of respondents were 36-45 years old (33.3\%), with female gender (59.4\%), high school education (51.1\%), work as private employees (40.6\%). Based on the results of univariate analysis, it was found that respondents aged 40 years (55.6\%), female (59.4\%), had higher education (92.8\%), worked (62.2\%), good knowledge ( $80 \%)$, positive attitude (78.3\%), sources of information sourced from social networks (60\%), good family support (55\%), good health worker support (61.1\%) and COVID-19 prevention behavior good (85\%). Based on the results of the bivariate analysis, it was found that there was a significant relationship between knowledge ( $p$ value $=0.000)$, attitudes ( $p$-value $=0.000)$, family support $(p$-value $=0.000)$, health worker support $(p$-value $=0.000)$ and behavior. prevention of COVID-19. However, there was no relationship between age $(p$-value $=0.529)$, gender $(p$-value $=0.848)$, education $(p$-value $=0.417)$, occupation $(p$-value $=$ 0.155 ), source of information ( $p$-value $=1,000$ ), with COVID-19 preventive behavior. Suggestions related to the results of the research are expected that $R W$ administrators can work together with health workers to increase knowledge, attitudes, and family support related to COVID-19 prevention behavior by encouraging, reminding, and educating the public regarding COVID-19.

Keywords: Community, preventive behavior, COVID-19 


\section{INTRODUCTION}

Coronavirus Disease 2019 (COVID-19) is an infectious disease caused by a new type of coronavirus named Severe Respiratory Coronavirus 2 (SARS-CoV-2) that has acute symptoms such as fever, cough, and shortness of breath with an average incubation period of 5-6 days to the longest for 14 days and severe symptoms such as pneumonia, acute respiratory syndrome, kidney failure, and death.

At the end of December 2019, five patients who had acute respiratory problems and one of them died with an initial diagnosis of pneumonia investigated to be related to the Seafood Market in Wuhan, Hubei Province, China, and until mid-January 2020 reported in 25 provinces in districts and cities in China found as many as 571 new cases. (Rothan \& Byrareddy, 2020).

Globally, the cumulative number of confirmed cases of COVID-19 as of March 21, 2021, was $122,536,880$ cases with 2,703,780 deaths. By region, the highest confirmed cases of COVID-19 are in the United States, with 53,937,714 cases with 1,299,243 deaths. Meanwhile, in Southeast Asia reported cumulatively the number of confirmed cases of COVID-19 as of March 21, 2021, as many as $14,182,826$ cases with 214,790 deaths, of which the country with the highest number of cases in Southeast Asia is India which is 11,599,130 cases with 159,755 deaths, Then followed by Indonesia as many as $1,455,788$ cases with 39,447 deaths. (WHO, 2021).

In Indonesia, the cumulative number of confirmed cases of COVID-19 as of March 21, 2021, was recorded at 1,460,184 cases with 129,844 active cases, 1,290,790 confirmed cases, and 39,550 deaths. Based on the provinces, there are 5 provinces with the highest number of cases, namely DKI Jakarta (370,581 cases), West Java (239,951 cases), Central Java (164,392 cases), East Java (136,680 cases), and East Kalimantan (61,577 cases).

While in Banten Province, the number of confirmed cases of COVID-19 cumulatively as of March 21, 2021, was recorded as many as 34,600 cases with 6,333 active cases, 27,645 cases cured, and 622 deaths (COVID-19 Handling Task Force, 2021).

South Tangerang city became the second-ranked city with the highest number of cases in Banten Province, which was 5,290 cases, and the second with the highest cumulative incidence of 447.24 cases per 100,000 residents (COVID-19 Handling Task Force, 2021).

Based on the District, Pamulang District became the second district with the highest number of cases, which is 1,976 cases, and based on the village, Bambu Apus Village is included in the five villages with the highest number of cases, namely as many as 177 cases with 655 close cases, 173 suspect cases and 9 deaths (Task Force COVID-19 South Tangerang City, 2021).

Research conducted in the jabodetabek region found $53.8 \%$ of respondents had poor COVID19 prevention behavior and found that respondents who had less family support (68.9\%), less health support (67.6\%), and information sources in the form of social networks (57\%) had poor COVID-19 preventive behavior. The results also showed that sources of information $(\mathrm{p}=0.049)$, family support 
( $\mathrm{p}=0.000)$, and health worker support $(\mathrm{p}=0.000)$ had a meaningful relationship with COVID-19 prevention. Then based on research conducted on pulmonary TB patients at Jember Lung Hospital TB Clinic showed that $50 \%$ of respondents with less knowledge and $95 \%$ of respondents with fewer attitudes had less COVID-19 preventive behavior, there was also a significant relationship between knowledge $(\mathrm{p}=0,000)$ and attitude $(\mathrm{p}=, 000)$ with COVID-19 prevention behavior (Wulandari, 2021). Based on this, the researchers aimed to examine the relationship of knowledge, attitudes, sources of information, family support, and support of health workers with COVID-19 prevention behavior in the community in Bambu Apus Village Area, Pamulang Subdistrict.

\section{METHODS}

This study is a quantitative analytical study with a cross-sectional approach, where data retrieval is done primarily with a questionnaire measuring tool conducted using Google form media in the form of questionnaires. The sample in this study amounted to 180 respondents where the sampling began by determining the minimum sample in each Rukun Tetangga with Probability Proportional to Size Sampling (PPS).

Then the dependent variables in the study were COVID-19 preventive behavior and the depen variables were age, gender, education, employment, knowledge, attitudes, sources of information, family support, and health worker support. This research was conducted in the community in the RW Region. 001 Bambu Apus Village, Pamulang District in 2021.

\section{RESULTS AND DISCUSSIONS}

Table 1. Independent and Condensed Variable Frequency Distribution

\begin{tabular}{lll}
\hline Variable & $\mathbf{n}$ & \% \\
\hline Ages & & \\
Age $<40$ Years & 80 & 44,4 \\
Age $\geq 40$ Years & 100 & 55,6 \\
Gender & & 40,6 \\
Man & 73 & 59,4 \\
Women & 107 & 7,2 \\
Education & & 92,8 \\
Low education & 13 & 37,8 \\
High education & 167 & 62,2 \\
Job & & \\
Unemployement & 68 & 60 \\
Employee & 112 & 40 \\
Source of information & & \\
Social media & 108 & 20 \\
News media & 72 & 80 \\
Knowledge & & 21,7 \\
Less good & 36 & 78,3 \\
Good & 144 & \\
Attitude & & \\
Negative & 39 & \\
Positive & 141 & \\
Family Support & & \\
& &
\end{tabular}




\begin{tabular}{lll}
\hline Variable & n & \% \\
\hline Less good & 81 & 45 \\
Good & 99 & 55 \\
Health Care Support & & \\
Less good & 70 & 38,9 \\
Good & 110 & 61,1 \\
\hline
\end{tabular}

Table 2. Results of Independent Variable Bivariate Analysis with Dependent Variables in Communities in the rw region. 001 Bambu Apus Village, Pamulang District in 2021

\begin{tabular}{|c|c|c|c|c|c|c|c|c|}
\hline \multirow{3}{*}{ Variable } & \multicolumn{6}{|c|}{ Covid-19 Prevention Behavior } & \multirow{3}{*}{$\begin{array}{c}\text { P- } \\
\text { Value }\end{array}$} & \multirow{3}{*}{ OR $(95 \% \mathrm{CI})$} \\
\hline & \multicolumn{2}{|c|}{ Less good } & \multicolumn{2}{|c|}{ Good } & \multicolumn{2}{|c|}{ Total } & & \\
\hline & $\mathbf{n}$ & $\%$ & $\mathbf{n}$ & $\%$ & $\mathbf{n}$ & $\%$ & & \\
\hline \multicolumn{9}{|l|}{ Ages } \\
\hline Age $<40$ Years & 10 & 12,5 & 70 & 87,5 & 80 & 100 & 0,529 & \multirow{2}{*}{$\begin{array}{l}0,697 \quad(0,300- \\
1,621)\end{array}$} \\
\hline Age $\geq 40$ Years & 17 & 17,0 & 83 & 83,0 & 100 & 100 & & \\
\hline \multicolumn{9}{|l|}{ Gender } \\
\hline Men & 13 & 13,7 & 63 & 86,3 & 73 & 100 & 0,848 & \multirow{2}{*}{$\begin{array}{l}0,840 \\
(0,361-1,956)\end{array}$} \\
\hline Women & 17 & 15,9 & 90 & 84,1 & 107 & 100 & & \\
\hline \multicolumn{9}{|l|}{ Education } \\
\hline Low education & 3 & 23,1 & 10 & 76,9 & 13 & 100 & 0,417 & \multirow{2}{*}{$\begin{array}{lll}1,788 & (0,458 \quad- \\
6,969) & & \end{array}$} \\
\hline High education & 24 & 14,4 & 143 & 85,6 & 167 & 100 & & \\
\hline \multicolumn{9}{|l|}{ Job } \\
\hline Unemployment & 14 & 20,6 & 54 & 79,4 & 68 & 100 & 0,155 & \multirow{2}{*}{$\begin{array}{ll}1,974 \quad(0,866- \\
4,503)\end{array}$} \\
\hline Employee & 13 & 11,6 & 99 & 88,4 & 112 & 100 & & \\
\hline \multicolumn{9}{|c|}{ Source of information } \\
\hline News media & 11 & 15,3 & 61 & 84,7 & 72 & 100 & 1,000 & \multirow{2}{*}{$\begin{array}{lll}0,964 & (0,449 & - \\
2,219) & & \\
\end{array}$} \\
\hline Social media & 16 & 14,8 & 92 & 85,2 & 108 & 100 & & \\
\hline \multicolumn{9}{|l|}{ Knowledge } \\
\hline Less good & 13 & 36,1 & 23 & 63,9 & 36 & 100 & \multirow[t]{2}{*}{0,000} & \multirow{2}{*}{$\begin{array}{lll}5,248 \quad(2,187 & - \\
12,596) & \\
\end{array}$} \\
\hline Good & 14 & 9,7 & 130 & 90,3 & 144 & 100 & & \\
\hline \multicolumn{9}{|l|}{ Attitude } \\
\hline Negative & 19 & 48,7 & 20 & 51,3 & 39 & 100 & \multirow[t]{2}{*}{0,000} & \multirow{2}{*}{$\begin{array}{l}15,794(6,105- \\
40,856)\end{array}$} \\
\hline Positive & 8 & 5,7 & 133 & 94,3 & 141 & 100 & & \\
\hline \multicolumn{9}{|l|}{ Family Support } \\
\hline Less good & 24 & 29,6 & 57 & 70,4 & 81 & 100 & \multirow[t]{2}{*}{0,000} & \multirow{2}{*}{$\begin{array}{l}13,474(3,883- \\
46,754)\end{array}$} \\
\hline Good & 3 & 3,0 & 96 & 97 & 99 & 100 & & \\
\hline \multicolumn{9}{|c|}{ Health Care Support } \\
\hline Less good & 23 & 32,9 & 47 & 67,1 & 70 & 100 & \multirow[t]{2}{*}{0,000} & \multirow{2}{*}{$\begin{array}{l}12,968(4,248- \\
39,585)\end{array}$} \\
\hline Good & 4 & 3,6 & 106 & 96,4 & 110 & 100 & & \\
\hline
\end{tabular}

Based on Table 2. It was obtained that there is no meaningful relationship between age, gender, education, employment, and COVID-19 prevention behavior in the community in RW. 001 Bambu Apus village, Pamulang subdistrict. Some risk factors have a meaningful association with Covid-19 prevention behavior. A respondent who has less good knowledge has a 5,248 times greater chance of having less good COVID-19 prevention behavior compared to respondents who have good knowledge. A respondent who has a negative attitude has a 15,794 times greater chance of having COVID-19 prevention behavior is less good than respondents who have a positive attitude. A respondent with poor family support has a 13.47 times greater chance of having less good COVID-19 prevention behavior than respondents with good knowledge. A respondent with the support of poor health workers has a 
12,968 times greater chance of having less good COVID-19 prevention behavior than respondents with good knowledge.

Based on the results of the study found that respondents who have a $\geq$ age of 40 years with COVID-19 prevention behavior are less good by $17.0 \%$ compared to respondents who have a < age of 40 years with poor preventive behavior of $12.5 \%$. Chi-square's statistical test results found that there was no meaningful relationship between age and COVID-19 prevention behavior(p-value $=0.397$ ).

The results of the study are not in line with research conducted on the head of the family in Pakijangan, Brebes related to dengue prevention behavior where there is a relationship between age and dengue prevention behavior $(p$-value $=0.457$ ) (Maulida, 2016).

A person's age influences the pattern of thought and how one learns an object. Increasing one's age will also increase the mindset and capture in understanding something so that the knowledge gained will also be better (Khairunnisa, Sofia, and Magfirah, 2021).

Based on the results of the study, female respondents with COVID-19 prevention behavior were less good by $15.9 \%$ compared to respondents of male sex with less good preventive behavior by $13.7 \%$. Chi-square statistical test results found that there is no meaningful relationship between knowledge and COVID-19 preventive behavior ( $\mathrm{p}$-value $=0.848$ ).

This is in line with research conducted on traditional market traders where there was no relationship between sex and health protocol behavior( $p$-value $=0.848$ ) (Supriyadi, Istanti, and Erlita, 2021).

But this study contradicts happens statement (2002) in Maulida (2016) and prevention behavior where men are the heads of families who have the opportunity to get information related to environmental health counseling where almost all participants are attended by men.

Based on the results of the study found that respondents who have low education with COVID19 preventive behavior are less good as much as $23.1 \%$ compared to respondents who have low education with less preventive behavior as much as $14.4 \%$. Chi-square statistical test results found that there is no meaningful relationship between education and COVID-19 preventive behavior (p-value $=0.417)$.

This is contrary to research conducted in North Sulawesi, there is a relationship between education and COVID-19 prevention behavior $(p$-value $=0.000)$ with $85.2 \%$ of respondents with higher education having good COVID-19 prevention behavior (Gannika, Lenny \& Sembiring, 2020). The level of education will affect a person's knowledge, especially health knowledge, which will also affect his behavior as a result of health education obtained (Putri and Naftassa, 2016).

Based on the results of the study found that respondents who did not work with COVID-19 prevention behavior are less good, which is as much as $20.6 \%$ compared to respondents working with 
poor preventive behavior which is $11.6 \%$. Chi-square statistical test results also found that there was no meaningful relationship between work and COVID-19 prevention behavior ( $p$-value $=0.155$ ).

This is contrary to research conducted by Suhermanto (2020) where it was found that the relationship between work and COVID-19 19 transmission prevention behavior ( $\mathrm{p}$-value $=0.007$ ) with $80.6 \%$ of respondents not working had good preventive behavior.

Harmani and Hamal (2013) in Maulida (2016) stated that someone who does not have a job has more time and opportunity to do cleanliness activities at home which is indirectly an effort to prevent DENGUE. But in his study, there was no relationship between work and dengue prevention behavior $(p$-value $=0.0,189)$.

Based on the results of the study, respondents with information sources from the news media had poor COVID-19 prevention behavior, which was $15.3 \%$ compared to respondents with information sources from social networks, which amounted to $14.8 \%$. Chi-square's statistical test results also showed that there was no relationship between the source of information and the COVID-19 prevention behavior ( $p$-value $=1,000)$.

The results of the study in contrast to the results of research conducted by Kundaryanti, Suciawati, and Solehah (2020) in pregnant women also showed a relationship between sources of information and prevention behavior of COVID-19 transmission ( $\mathrm{p}$-value $=0.03$ ).

The source of information is everything that becomes an intermediary in conveying information, information media for mass communication that can be obtained through print media such as newspapers and magazines, or electronic media such as television, radio, and the internet, and through activities carried out by health workers (Notoadmodjo, 2003). The information circulating about COVID-19 and the knowledge or experience ever obtained provides signals to form a good perception or not good in implementing COVID-19 prevention behavior (Prastyawati et al., 2021)

Based on the results of the study found that respondents who have poor knowledge with poor COVID-19 prevention behavior by $36.1 \%$ compared to respondents who have good knowledge with poor behavior as much as $9.7 \%$. Chi-square statistical test results also showed that there is a meaningful relationship between knowledge and COVID-19 preventive behavior ( $p$-value $=0.000)$. This research is in line with research conducted on the community in Potorono Banguntapan Bantul Hamlet, Yogyakarta where there is a relationship between knowledge and COVID-19 prevention behavior $(p$-value $=0.001$ ) (Mujiburrahman, Riyadi, and Ningsih, 2020).

Research conducted by Kurniasih and Widianingsih (2013) related to the prevention behavior of TB transmission in people with pulmonary TB found that there is a significant relationship between knowledge and TB transmission prevention behavior $(p$-value $=0.008)$. The process of forming a prevention behavior of transmission is motivated by several factors including knowledge or information obtained, as well as an understanding of the information obtained before finally someone makes a 
concrete action in the form of preventive behavior of pulmonary TB transmission (Kurniasih and Widianingsih, 2013).

Knowledge is a result of human sensing or the result of one's understanding of an object using his senses that are influenced by the intensity of one's attention and perception of an object (Notoadmodjo, 2014).

Based on the results of the study, respondents who had a negative attitude with COVID-19 prevention behavior were less than $48.7 \%$ compared to respondents who had a positive attitude with less behavior as much as $5.7 \%$. Chi-square statistical test results also found that there is a significant relationship between attitudes and COVID-19 prevention behavior ( $\mathrm{p}$-value $=0.0000$ ).

This study is in line with research conducted on residents of Kemuningsari Kidul Village where there is a relationship between attitudes and COVID-19 prevention behavior $(p$-value $=0.007$ ) (Aini and Purwasari, 2021).

Attitude is a person's closed acceptance of an internal or external stimulus or object whose embodiment or form is not directly visible but can be interpreted earlier from a closed behavior (Sunaryo, 2004).

Campbel (1950) defines attitude as a syndrome or set of symptoms in response to a stimulus or an object so that it includes thoughts, feelings, attention, and other psychiatric symptoms (Notoadmodjo, 2014).

Based on the results of the study found that respondents who have poor family support with less good COVID-19 prevention behavior are greater than $29.6 \%$ compared to respondents who have good family support which is as much as $3 \%$. Chi-square statistical test results also found a link between family support and COVID-19 prevention behavior ( $p$-value $=0.000$ ).

Based on the results of the study found that respondents who have poor family support with less good COVID-19 prevention behavior are greater than $29.6 \%$ compared to respondents who have good family support which is as much as $3 \%$. Chi-square statistical test results also found a link between family support and COVID-19 prevention behavior ( $p$-value $=0.000$ ).

Pender (2000) in Nurlita (2017) defines social support as interpersonal negotiations involving emotional attention (expression of caring, encouragement, empathy), help (services, money, and information), and appreciation (constructive, feedback, recognition).

Family support is a process of relationship between families with a social environment that is supportive and provides assistance to family members (Melisa, 2017)

Based on the results of the study found that respondents who have poor health worker support with poor preventive behavior by $32.9 \%$ compared to respondents who have good health support of 3.6\%. Chi-square statistical test results found that there is a relationship between social support of health workers and COVID-19 preventive behavior $(p$-value $=0.000)$. 
The results of the study in line with research conducted by Nurlita, (2017) related to hypertension prevention behavior in the elderly showed that $53.3 \%$ of respondents received poor health support and gained a significant relationship ( $\mathrm{p}$-value $=0.000)$.

Health support is done by providing comfort both physical and psychological, giving attention, appreciation, and assistance in any form that can be received by a person. In carrying out their duties, health workers as motivators provide assistance, awareness, and encourage a group or individual to understand a problem at hand and can independently develop the existing potential to solve the problem (Riakasih, Hayati, and Rahman, 2020).

At this time, health workers are a professional group that has an important role in the COVID19 pandemic period were not only to provide care for patients in need but also provide examples of good preventive behavior that causes community independence. Health workers also provide positive knowledge or understanding related to COVID-19. The understanding provided by health workers will create attitudes that can form measures in the form of pandemic prevention and countermeasures.

\section{CONCLUSIONS AND SUGGESTIONS}

Based on the results of research that has been conducted by researchers in the Community in the RW region. 001 Bambu Apus Village, Pamulang Subdistrict can be concluded that:

1. The univariate analysis found that respondents aged $\geq 40$ years (55.6\%), women (59.4\%), higher education (92.8\%), working (62.2\%), good knowledge (80\%), positive attitudes (78.3\%), sources of information sourced on social networks (60\%), good family support (55\%), good health support (61.1\%) and good COVID-19 preventive behavior (85\%).

2. Based on the results of bivariate analysis, there is a meaningful relationship between knowledge ( $p$-value $=0.000)$, attitude $(p$-value $=0.000)$, family support $(p$-value $=0.000)$, health worker support $(p$-value $=0.000)$ with COVID-19 prevention behavior in communities in RW. 001 Bambu Apus Village, Pamulang Subdistrict. However, there was no relationship between age $(p$-value $=0.529)$, gender $(p$-value $=0.848)$, education $(p$ value $=0.417)$, employment $(p$-value $=0.155)$, source of information $(p$-value $=1,000)$, with preventive behavior COVID-19.

Suggestions related to the results of the study are expected RW administrators can work with health workers to improve knowledge, attitudes, and family support related to COVID-19 prevention behavior by encouraging, reminding, and educating the community related to COVID-19.

\section{THANKYOU-NOTE}


Peneliti mengucapkan terimakasih kepada Fakultas Kesehatan Masyarakat Universitas Muhammadiyah Jakarta, Ketua RW. 001 Kelurahan Bambu Apus beserta jajarannya yang telah membantu dan mendukung dalam pelaksanaan penelitian ini.

\section{REFERENCES}

Aini, N.-, \& Purwasari, M. D. (2021). Sikap dan Perilaku Pencegahan Covid-19 di Desa

Kemuningsari Kidul Kabupaten Jember. Jurnal Kesehatan, 8(3), 171-177.

https://doi.org/10.25047/j-kes.v8i3.176

Gannika, Lenny \& Sembiring, E. (2020). Tingkat Pengetahuan dan Perilaku Pencegahan Coronavirus Disease 2019 (COVID-19) Pada Masyarakat Sulawesi Utara Lenny Gannika. NERS: Jurnal Keperawatan, 16(2), 83-89.

Gugus Tugas COVID-19 Kota Tangerang Selatan. (2021). Data Pantauan COVID-19 Kota

Tangerang Selatan. Gugus Tugas COVID-19 Kota Tangerang Selatan.

Khairunnisa, Sofia, R., \& Magfirah, S. (2021). HUBUNGAN KARAKTERISTIK DAN TINGKAT

PENGETAHUAN DENGAN PERILAKU PENCEGAHAN COVID-19PADA MASYARAKAT

DESA PAYA BUJOK BLANG PASE KOTA LANGSA. 6(1), 1-11.

Kundaryanti, R., Suciawati, A., \& Solehah. (2020). Faktor-Faktor yang Berhubungan dengan

Perilaku Pencegahan Penularan Covid-19 pada Ibu Hamil Tahun 2020.

Kurniasih, N. D., \& Widianingsih, C. (2013). Pencegahan Penularan Tb Pada Penderita Tb Paru Di

Poli Paru Rumah Sakit Prof . Dr . Sulianti Saroso. The Indonesian Journal of Infectious Disease, 28-31.

Maulida, I. (2016). Analisis Hubungan Karakteristik Kepala Keluarga Dengan Perilaku Pencegahan

Demam Berdarah Di Pakijangan Brebes. Info Kesehatan, 6(1), 1-5.

Melisa, T. (2017). Hubungan dukungan keluarga dengan perilaku pencegahan pada klien

tuberkulosis paru di wilayah kerja puskesmas cimareme tahun 2017.

Mujiburrahman, Riyadi, \& Ningsih. (2020). Pengetahuan Berhubungan dengan Peningkatan Perilaku Pencegahan COVID-19 di Masyarakat. Jurnal Keperawatan Terpadu, 2(2), 130-140.

Notoadmodjo. (2003). Pendidikan dan Perilaku Kesehatan. Penerbit Rineka Cipta.

Notoadmodjo, S. (2014). Ilmu Perilaku Kesehatan. PT Rineka Cipta.

Nurlita, W. A. (2017). Hubungan Dukungan Tenaga Kesehatan dengan Perilaku Pencegahan

Hipertensi Landia di Posyandu Nurus-Asfa RW 01 Kelurahan Tlogomulyo.

Prastyawati, M., Fauziah, M., Ernyasih, Romdhona, N., \& Herdiansyah, D. (2021). Faktor-faktor yang Berhubungan dengan Perilaku Pencegahan COVID-19 Mahasiswa FKM UMJ pada Pandemi COVID-19 Tahun 2020. AN-NUR : Jurnal Kajian Dan Pengembangan Kesehatan Masyarakat, 1, 173-184. https://doi.org/10.24853/an-nur, 1, 2, 173 - 184

Putri, R., \& Naftassa, Z. (2016). Hubungan Tingkat Pendidikan dan Pengetahuan Masyarakat dengan 
Perilaku Pencegahan Demam Berdarah dengue di Desa Kemiri,Kecamatan Jayakerta, Karawang tahun 2016. MAGNA MEDICA: Berkala Ilmiah Kedokteran Dan Kesehatan, 1(4), 1. https://doi.org/10.26714/magnamed.1.4.2017.1-7

Riakasih, E., Hayati, R., \& Rahman, E. (2020). FAKTOR-FAKTOR YANG BERHUBUNGAN DENGAN PERILAKU UPAYA PENCEGAHAN PENULARAN TB PARU PADA PENDERITA TB PARU DI WILAYAH KERJA PUSKESMAS PUNDUTAHUN 2020.

Rothan, H. A., \& Byrareddy, S. N. (2020). The epidemiology and pathogenesis of coronavirus disease (COVID-19) outbreak. Journal of Autoimmunity, 109(February), 102433. https://doi.org/10.1016/j.jaut.2020.102433

Satuan Tugas Penanganan COVID-19. (2021). ANALISIS DATA COVID-19 INDONESIA Update per 21 Maret 2021.

Suhermanto. (2020). Perilaku Masyarakat dalam Pencegahan Penularan Covid-19. 4, 91-96.

Sunaryo. (2004). PSIKOLOGI UNTUK KEPERAWATAN (M. Ester (ed.)). Penerbit Buku Kedokteran EGC.

Supriyadi, Istanti, N., \& Erlita, Y. D. (2021). Perilaku Protokol Kesehatan Covid 19 Pada Pedagang Pasar Tradisional. Jurnal Keperawatan, 13(1), 213-226.

WHO. (2021). COVID-19 Weekly Epidemiological Update.

Wulandari, S. (2021). HUBUNGAN PENGETAHUAN DAN SIKAP DENGAN PERILAKU PENCEGAHAN COVID-19 PADA PENDERITA TUBERKULOSIS DI RUMAH SAKIT PARU JEMBER. 